\title{
PERKEMBANGAN ISLAM DI PULAU AMBALAU: Kajian atas Data Arkeologi dan Tradisi Makam Islam Berundak
}

\author{
Islamic Development In The Ambalau Island: \\ Study on Archaeological Data and Islamic Traditional Tomb Staircase
}

\author{
Wuri Handoko \\ Balai Arkeologi Ambon \\ J1. Namalatu-Latuhalat, Nusaniwe, Ambon-97118 \\ wurhand@yahoo.co.id
}

\begin{abstract}
Abstrak
Kajian terhadap perkembangan Islam salah satunya menyangkut apek karakteristik Islam dapat dilihat melalui lensa arkeologi berdasarkan temuan artefak maupun fitur. Dalam aspek budaya material tersebut, dapat memperlihatkan perkembangan nilai budaya yang terkandung dalam konteks sistem dan transformasi nilai budaya sejak masa lampau hingga kini. Data arkeologi yang menunjukkan karakter megalitis hingga data arkeologi Islam serta tradisi keagamaan yang berlaku pada mayarakat Ambalau, memberikan gambaran tentang perkembangan religi mayarakat lokal sejak kepercayaan atau religi masa prasejarah hingga munculnya Islam. Dari data arkeologi dan tradisi yang masih bertahan, memberikan gambaran bahwa agama Islam berkembang dengan tetap mengakomodir kepercayaan lokal yang berbasis pada kepercayaan terhadap leluhur. Bentuk makam kuno berundak, adalah salah satu wujud material budaya yang menggambarkan bahwa masyarakat sangat menghormati leluhur.
\end{abstract}

Kata Kunci : Islam, makam kuno, kepercayaan, tradisi, lokal

\begin{abstract}
The study on the development of Islam one of which involves stale Islamic characteristics can be seen through the lens based on the findings of archaeological artifacts and features. In the aspect of material culture, can show the development of cultural values embodied in the context of the system and transformation of cultural values from the past until now. Archaeological data indicate that the data character megalitis Islamic archeology and religious traditions prevailing in society Ambalau, gives an overview of the development of local people's religious beliefs or religious since prehistoric times until the advent of Islam. Of archaeological data and traditions still survive, giving the impression that Islam evolved with fixed accommodate local beliefs based on trust towards ancestors. The shape of an ancient tomb staircase, is one manifestation of cultural material that illustrates that the community is honoring ancestors.
\end{abstract}

Keywords: Islam, ancient tombs, beliefs, traditions, local

\section{PENDAHULUAN}

\section{Latar Belakang}

Makam dan masjid, adalah penanda arkeologi yang paling dominan dan penting dalam melihat perkembangan Islam di wilayah penelitian. Dari keseluruhan data arkeologis di wilayah penelitian, sebagai wilayah kultural Islam, menunjukkan bahwa masjid dan makam adalah data yang paling utama, menggambarkan bagaimana Islam berkembang di wilayah-wilayah penyebarannya. Terutama sekali masjid, menjadi ikon utama, atau penanda paling spesifik dan paling jelas, bagaimana Islam tumbuh dan berkembang di wilayah Maluku. Masjid dapat dianggap sebagai ikon atau 
ciri utama sebuah situs Kerajaan Islam, hal ini karena dalam tradisi Islam sejak Nabi Muhammad SAW pendirian kerajaan Islam senantiasa didahului dengan pembangunan masjid serta dianggap sebagai pusat kegiatan dalam segala aspek kehidupan umat (Salam, 1960:19; Gazalba, 1966; Mahmud, 2003: 40). Dengan demikian masjid adalah simbol utama keberagamaan umat Islam, menjadi pusat orientasi dan sumber utama memperoleh kebajikan dan pengetahuan menjadi bagian inspirasi manusia untuk memperoleh segala kemuliaan sekaligus tempat mensucikan diri.

$$
\text { Pembahasan mengenai ragam }
$$

tinggalan arkeologi Islam, selain masjid kuno, yang lain diantaranya adalah makammakam kuno, merupakan perbincangan yang selalu mewarnai setiap pembahasan tentang karakter dan dinamika Islam di wilayah Nusatara. Makam Kuno sebagai salah sat fitur Islam, sejauh ini selalu dihubungkan dengan bagaimana model keberlanjutan tradisi ketika Islam menjadi agama yang dikonversi masyarakat secara luas. Hal in karena makam kuno, sebagai artefak dan fitur Islam, dapat memberikan gambaran bagaimana perkembangan akulturasi antara Islam dan elemen-elemen budaya loka yang bertahan. Ambary (1998) mengatakan, bahwa dalam aspek budaya material, refleksi sosialisasi Islam Nusantara, banyak dipengaruhi antara lain: pertama, kenyataan historis serta realitas sosial pada saat Islam di sosialisasikan; kedua, hasil identifikasi terhadap dasar legitimasi kultural untuk diterimanya Islam; dan ketiga, proses serta strategi yang dikembangkan secara loka dalam sosialisasi Islam (Ambary, 1998:195). Penjelasan Ambary tersebut susungguhnya menjelaskan bahwa Islam berkembang karena menerapkan strategi sosialisasi yang mengadaptasi budaya lokal, dimana Islan disosialisasikan, di wilayah setempat, ha ini karena sebelum Islam berkembang, masyarakat telah mengenal sistem kepercayaan atau religi yang berkembang sebelum Islam.
Karakteristik data arkeologi Islam yang demikian tampaknya juga menonjo di wilayah Pulau Ambalau, yang diketahui sebagai satu wilayah pemukiman komunitas Islam di Maluku. Pulau Ambalau yang merupakan pulau kecil di sebelah tenggara Pulau Buru (terletak pada koordinat $3^{\circ} 52>17 »$ LS $127^{\circ} 12>12 » \mathrm{BT}$ ), adalah pulau yang terbentuk karena proses vulkanik sehingga pulau ini umumnya berupa tebing karang terjal akibat dari proses pengangkatan dasar laut ke permukaan. Penelitian arkeolog di Pulau Ambalau menitik beratkan pada data arkeologi yang ada di tiga desa yaitu Desa Masawoy, Desa Ulima, dan Desa Siwar.

Tulisan ini akan membahas karakteristik keberagaamaan Islam pada masyarakat Ambalau, khususnya dalam tinjauan tradisi pemakaman masyarakat dan perkembangan Islam setempat. Survey dipusatkan dalam wilayah pusat desa, yang sekaligus sebagai ibukota kecamatan. Hasil survey masih diperoleh data arkeologi yang minim. Dalam konteks pengamatan terhadap benda-benda koleksi penduduk, terdapat kepercayaan masyarakat Ambalau khususnya di ketiga desa tersebut masih sangat kuat terhadap kekuatan dari pengaruh ruh nenek moyangnya yang akan menentukan baik buruknya atau berhasil atau tidaknya semua aktivitas mereka yang sedang dan akan dilaksanakan. Sehingga data kepurbakalaan yang masih disimpan atau dikeramatkan tidak bisa dikunjungi kalau tidak pada waktunya. Menurut informan dikatakan bahwa waktu yang tepat untuk dapat mengunjungi atau melihat semua data kepurbakalaan di desa tersebut harus datang pada Hari Raya Maulud. Pada Hari Raya Maulud tersebut semua benda-benda keramat akan disajikan kepada semua pengunjung yang hadir di sana (Sudarmika, 1997, Tim Penelitian, . berdasarkan temuan data arkeologi berupa artefaktual yang terdapat di permukaan yang tidak menjadi koleksi penduduk serta kajian terhadap tradisi makam kuno Islam di Pulau Ambalau, terutama di desa Siwar.

\section{Rumusan Masalah}

Di wilayah Maluku, masyarakat tradisional di wilayah ini adalah masyarakat yang sangat kuat mempertahankan tradisi, sehingga ketika Islam masuk, anasir-anasir budaya lokal tidak bisa dihilangkan begitu saja. Bentuk perkembangan sosial budaya masyarakat dianyatanya adalah aspek religi, dari perkembangan religi masa pra agama hingga munculnya agama (Islam). Tradisi kepercayaan lokal hingga munculnya Islam, sesungguhnya dapat diidentifikasi berdasarkan tinggalan arkeologinya. Bentukbentuk akomodatif islam dengan budaya lokal, dalam berbagai aspek dapat ditinjau dari karakteristik budaya material yang dihasilkan baik itu berbentuk bangunan atau fitur maupun data artefaktual. Salah satu data arkeologi yang dapat menggambarkan bagaimana keberagamaan Islam masyarakat lokal adalah wujud fisik makam-makam kuno.

1. Bagaimana bentuk perkembangan religi lokal masyarakat Pulau Ambalau berdasarkan data arkeologi?

2. Bagaimana karakteristik Islam berdasarkan data tradisi makam Kuno di Pulau Ambalau?

\section{Metode Penelitian}

Penelitian ini merupakan penelitian deskkriptif kualitatif, yakni penelitian yang menekankan pada deskripsi data arkeologi melalui pengamatan. Metode penelitian ini dilakukan melalui survey untuk mengumpulkan dan mendeskripsikan data arkeologi di permukaan tanah, secara khusus data makam kuno. Deskripsi bentuk makam dilakukan membangun interpretasi. Selain itu data etnografi yang dihasilkan melalui wawancara juga sangat penting Interpretasi dilakukan dengan mengintegrasikan bentukbentuk makam dengan hasil wawancara dan studi pustaka yang berkaitan dengan sejarah Islamisasi dan tradisi-tradisi lokal yang berkembang di wilayah penelitian.
HASIL DAN PEMBAHASAN

Sekilas Tentang Setting Etnografi Pulau Ambalau

Berdasarkan garis keturunan, penduduk Ambalau dibagi menjadi dua yaitu penduduk asli dan penduduk pendatang. Penduduk pendatang umumnya pindah ke Ambalau karena faktor perkawinan dan umumnya berasal dari Bugis dan Buton serta sedikit Jawa. Seperti halnya daerah lain di Maluku, masyarakat Ambalau juga membedakan garis keturunan berdasarkan sistem kekerabatan yang diambil dari pihak ayah (patrilineal), dan dicantumkan pada nama belakang yang menjadi nama marga/keluarga (soa). Beberapa marga di Pulau Ambalau diantaranya marga Booy, Tukmuly, Saliu, Loilatu, Soulissa, Souwakil, Latuconsina da lain-lain. Sistem keturunan ini dipengaruh oleh sistem Petuanan (Regentshape) (suatu pemerintahan warisan zaman penjajahan Belanda) dan sekaligus sistem adat lokal.

Sistem adat lokal telah membagi peranperan sesuai marga masing-masing, dimana ada marga yang menjadi raja, ada yang menjadi kewang, ada yang menjadi kapitan, ada yang menjadi penghulu dan lain-lain dan peran tersebut akan diturunkan kepada keturunan dari marga tersebut dan tidak akan diserahkan kepada marga lain. Sebagai contoh, latupati akan menjadi hak marga Loilatu dan penghulu menjadi hak marga Booy. Sebaga informasi, berdasar sistem petuanan di Buru Selatan terdiri dari 4 petuanan yaitu Masarete, Ambalau, Fogi dan Waesama. Berdasarkan pembagian administrasi saat ini, petuanan Fogi meliputi daerah Kepala Madan, petuanan Masarete meliputi daerah Leksula dan sebagian Namrole, Waisama meliputi sebagian daerah Namrole dan Waisama, serta Ambalau yang meliputi seluruh daerah Pulau Ambalau. Masing-masing petuanan memiliki raja, latupati, kapitan dan pemimpin agama (penghulu).

Secara informal semua masyarakat menyepakati bahwa setiap keputusan harus dimusyawarahkan, dengan demikia musyawarah warga dan keputusan bersama 
ditempatkan sebagai kekuasaan tertinggi hukum adat. Kelembagaan pengaturan adat tertinggi ada pada Latupati (dewan raja) yang meliputi seluruh Pulau Ambalau. Kekuasaan latupati adalah menjadi otoritas kekuasaan adat yaitu menyangkut soal batas-batas tanah, pemanfaatan pembukaan lahan hutan misalnya untuk tambang dan persoala konflik antar negeri/desa, sedangkan konflik dalam satu desa cukup pada raja masingmasing desa. Sedangkan kelembagaan tradisisonnal secara otoritatif melekat (embeded) pada masing-masing pemerintahan desa (raja dan kewang) dan imam masjid (penghulu). Ini menunjukkan bahwa ada keseimbangan antara pemerintah, pimpinan adat dan tokoh masyarakat (agama) sebagai pemegang wewenang yang mengatur sistem sosial, namun imam masjid lebih memilik otoritas yang lebih tinggi dalam hal tertentu, misalnya tentang aturan tentang sasi, karena pengumuman penutupan dan pembukaan sasi, persidangan ada pelanggaran dilakukan $\mathrm{d}$ masjid, dan posisi hakim diserahkan kepada imam masjid. Struktur pemerintahan ada di wilayah Pulau Ambalau pada umumnya sama (Masawoy dan Ulima) dengan sistem legislatif-eksekutif-yudikatif dimana latupati sebagai legislatif, raja berperan sebaga eksekutif dan imam masjid berperan sebagai lembaga peradilan (yudikatif).

\section{Data Arkeologi dan Bentuk Perkembangan}

\section{Religi di Pulau Ambalau}

Desa Masawoy, meskipun bukan ibukota kecamatan, namun bisa dikatakan sebagai pintu masuk ke wilayah kecamatan Pulau Ambalau. Selain letaknya di depan, juga terdapat pelabuhan, tempat kapal dari berbagai pulau sekitar berlabuh. Masyarakat di wilayah Pulau ambalau, tergolong masyarakat yang terisolir, mengingat wilayahnya secara geografis merupakan wilayah pulau terpencil yang terisolir oleh kondisi laut dan cuaca yang ektrem serta minimnya moda transportasi untuk tujuan ke wilayah tersebut. Tampaknya inilah yang menyebabka masyarakatnya cenderung tertutup, apalagi informasi menyangkut kearkeologian atau kepurbakalaan yang menurut mereka tabu diperbincangkan karena banyak diantaranya berhubungan dengan roh para leluhur.

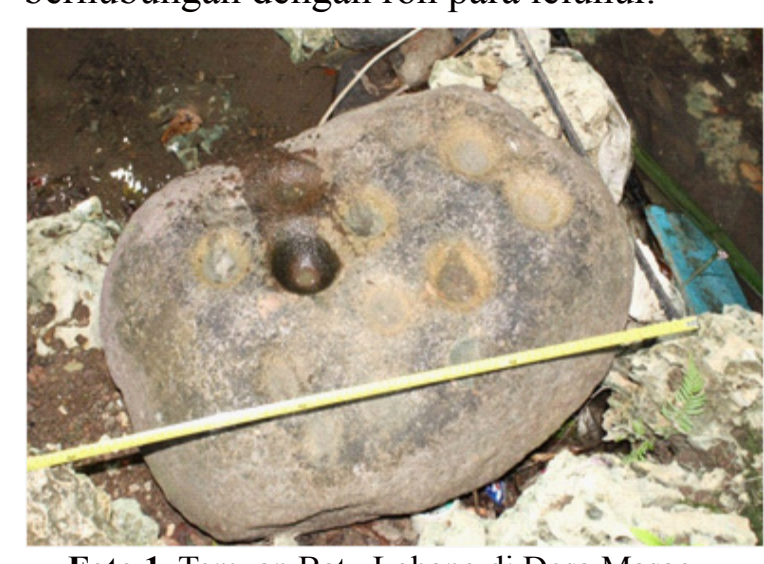

Foto 1. Temuan Batu Lobang di Desa Masaoy,

Arkeologi Ambon, 2011)

Sejumlah data arkeologi yang ditemukan, menunjukkan bahwa awa okupasi dan budaya masyarakat di wilayah Ambalau, tergolong sudah berlangsung dalam jangka waktu yang lama. Sejak masa megalitik, berdasarkan data arkeologi yang diperoleh, menunjukkan bahwa wilayah itu sudah dihuni, kemungkinan masa yang jauh lebih tua lagi, namun belum diperoleh bukti valid. Dari masa megalitik diantaranya diperoleh data berupa batu lubang, semacam batu berukuran besar yang dipermukaanya terdapat beberapa lobang dengan jumlah dan pola tertentu, yang Pada masa prasejarah, kemungkinan menjadi salah satu perangkat untuk upacara keagamaan. Batu lubang, ditemukan dipinggir sungai kecil di wilayah desa Masawoy, panjang batu 83 wilayan desa Mawoy, panjang batu 83 $\mathrm{cm}$, sedangkan lebar batu $65 \mathrm{~cm}$, dengan ketebalan batu mencapai $63 \mathrm{~cm}$. Batu in terdiri dari 14 lubang di permukaannya, masing-masing lobang berdiameter antara $7-13 \mathrm{~cm}$. Belum diperoleh data pendukung lainnya dalam lintasan budaya megalitik, namun temuan batu lubang, memberikan indikasi bahwa kehidupan di wilayah tersebut telah berlangsung lama dan kehidupan relig juga sudah dikenal sejak masa megalitik. Kemungkinan pengaruh tradisi megalitik juga terus bertahan hingga masuk dan berkembangnya Islam di wilayah tersebut. Temuan batu lobang merupakan salah satu data arkeologi peninggalan zaman megalitik. Batu lobang, ditemukan di sebuah sungai kecil di sebelah timur kampung, tepatnya sungai yang mengalir di depan masjid desa Masawoy, berjarak sekitar 100 meter dari tepi pantai (Tim Penelitian, 2011).

Data arkeologi hasil penelitian sebelumnya (Sudarmika, 1997), tinggalan arkeologi itu berupa sejumlah pahatan geometris di batu karang yang sangat terjal dan tidak jauh dari pantai. Lokasinya sekitar $4 \mathrm{~km}$. ke arah utara Desa Masawoy, situs tersebut oleh masyarakat setempat dikenal dengan nama batu klakoy. Batu dinding tersebut mempunyai tinggi sekitar 40 meter di atas permukaan air laut, mempunyai ceruk sepanjang dua meter, sedangkan tinggi ceruk dari permukaan tanah sekitar 273 $\mathrm{cm}$. dan panjangnya 8 meter. Data fisik dari tinggalan ini adalah berupa pahatan segitiga siku-siku yang berjumlah 32 buah pahatan segitiga, pahatan segitiga yang paling besar mempunyai ukuran 17 x $12 \mathrm{~cm}$. sedangkan yang paling kecil mempunyai ukuran 11 x $7 \mathrm{~cm}$. dari keseluruhan pahatan segitiga tersebut kesemuanya pada bagian tengahnya ada lubangnya, sehingga masyarakat Masawoy menyebutnya sebagai pahatan yang menggambarkan alat kelamin wanita. Selanjutnya oleh informan diterangkan pula bahwa tinggalan tersebut mempunyai legenda tersendiri. Diceritakan pula bahwa pada masa lampau ditempat tersebut adalah merupakan tempat untuk berkumpulnya kaum muda laki dan perempuan, sehingga pada suatu ketika seorang pemuda berjanji dengan kekasihnya untuk bertemu di tempat tersebut, pemuda ini lebih duluan menunggu kekasihnya karena terlalu lama pemuda ini menunggu sang kekasih tidak juga munculmuncul sehingga pemuda ini sangat kesal hatinya dan akhirnya pemuda yang sudah kecewa itu menggambar dengan memahat dinding batu yang ada disekitarnya itu yang menyerupai alat kelamin si wanita yang ditungguinya itu, dengan harapan wanita itu menjadi sangat malu karena alat kelaminnya banyak orang yang bisa mengetahuinya. Data penunjang yang ditemukan di sekitar pahatan geometris itu berupa gerabah lokal dari jenis periuk, mangkuk, dan piring, sedangkan data non artefak berupa tulang hewan dan kulit kerang atau siput. Situasi lingkungannya sangat subur banyak ditumbuhi kayu-kayu hutan dan belum dimanfaatkan sebagai tanah produktif. Asumsi sementara yang bisa dikemukakan berkenaan dengan situs tersebut adalah, bahwa pada masa lampau situs tersebut pernah dimanfaatkan sebagai tempat hunian sementara, sebab berdasarkan data yang berhasil diidentifikasi di sekitar areal situs yaitu berupa temuan artefak keramik lokal, dan non artefak berupa tulang hewan beserta kulit siput. Selain itu lingkungan situs yang terdiri dari tanah subur dan berada didekat lautu/pantai, sehingga likasi ini sangat setrategis untuk hunian yang bisa dimanfaatkan untuk memenuhi kehidupannya setiap hari yaitu dengan mengeksploitas kedua sumber daya alam tersebut (Sudarmika 1997)

Sementara itu hasil survey pada wilayah pusat desa, yang sekaligus sebagai ibukota kecamatan diperoleh data arkeologi yang minim. Namun, penelitian ini setidaknya telah menjumpai tradisi pemakaman yang berbeda dengan daerah lainnya. Lokas pemakaman beberapa diantaranya berada $\mathrm{d}$ dalam kampung baik dekat dengan rumah maupun dalam areal komplek masjid. Untuk tokoh masyarakat tertentu biasanya dimakamkan di areal masjid, atau di dekat rumah tinggal. Keunikan atau perbedaa yang khas dengan masyarakat lainnya di Maluku, adalah tradisi pemakaman dengan menggunakan jirat yang bersusun atau bertingkat atau berundak, seperti punden berundak yang dikenal pada masa megalitik. Tradisi pemakaman dengan jirat demikian menunjukkan adanya tradisi pra Islam yang masih terus bertahan. Undakan atau susunan jirat makam, biasanya berundak dua atau tiga, dengan ukuran jirat yang dari bawah besar 
semakin ke atas semakin kecil. Berdasarkan informasi penduduk, makam dengan jirat berundak menunjukkan status sosial si mati yang tinggi baik karena peran ataupun kedudukannya dalam masyarakat. Biasanya makam dengan jirat berundak diperuntukkan bagi makam raja dan keturunannya atau dalam hal ini keturunan marga raja atau marga perintah, atau makam Imam masjid. Informas lain juga menerangkan baha tradisi makam berundak diperuntukkan untuk kategori mayarakat tertentu, untuk makam dengan undakan 2 (dua) tingkat, adalah makam bag imam masjid dan keturunannya, sedangkan makam dengan undakan tiga tingkat adalah makam bagi penyebar Islam.

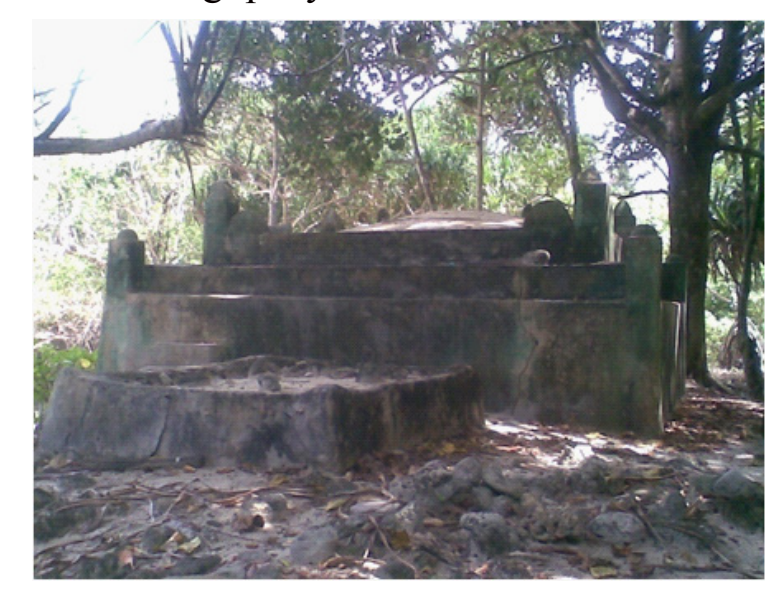

Foto 2. Makam tokoh penyebar Islam pertama Pulau Ambalau di Desa Siwar

(Sumber: Dok. Balai Arkeologi Ambon, tahun 2011).

Tradisi pemakaman ini menunjukkan karakteristik Islam yang berbeda dengan daerah lainnya. Beberapa tradisi memiliki kesamaan dengan di daerah Pelauw, Pulau Haruku. Kemungkinan pengaruh Islam dari wilayah Pulau Haruku, juga terdapat di wilayah ini. Salah satu indikasi misalnya nama marga Latuconsina, yang juga ada di desa Siwar.

Survey di Desa Ulima, terdapat majid kuno dan berbagai alat kelengkapan masjid yang maish tersimpan di dalam majid. Masjid Kuno Desa Ulima, terletak berdampingan dengan desa Masawoy, desa ini berada pada titik astronomis $\mathrm{S}$ $03^{\circ} 49.504^{\prime}$ dan E $127^{\circ} 10.639^{\prime}$. Masjid kuno di Desa Ulima, sudah banyak mengalami perubahan, dan menghilangkan ciri kekunoannya, baik dari segi bentuk maupun bahan. Ciri kekunoaannya hanya tampak pada tiang utama, berjumlah empat buah tiang di tengah ruangan. Selain itu berbagai kelengkapan masjid juga masih menunjukkan ciri kekunoannya diantaranya mimbar, alat pembakaran kemenyan, bedug dan timbangan zakat fitrah. Selain itu di dalam masjid, terdapat meriam kuno yang dikeramatkan. Oleh masyarakat, meriam tersebut dibungkus dengan kain putih. Sebagai tanda bahwa meriam kuno dianggap sebagai benda pusaka.

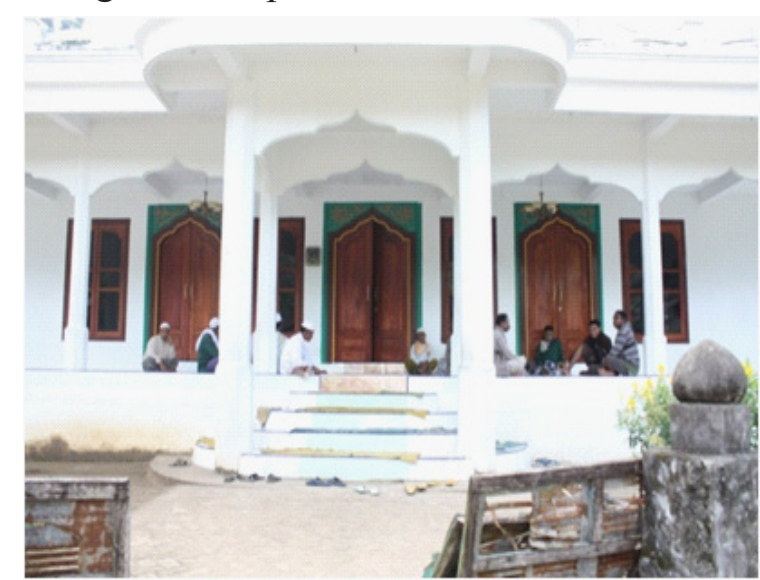

Foto 3. Masjid Kuno Ulima, yang banyak mengalami pembaruan dari segi konstruksi dan arsitekturalnya

(Sumber: Dok. Balai Arkeologi Ambon, 2011).

Di Desa Ulima juga diperoleh data arkeologi Islam berupa meriam kuno dan timbangan zakat fitrah. Data yang paling penting berupa meriam kuno panjang $156 \mathrm{~cm}$, disimpan dalam masjid dan dikeramatkan, terbukti meriam ini ditutup dengan kair berwarna putih dar isimpan di dalam masjid. Tidak diperoleh informasi sejarah lisan menyangkut keberadaan meriam ini di dalam masjid, namun belum bisa dipastikan meriam di Desa Ulima, Pulau Ambalau produk mana dan bagaimana prosesnya hingga berada di wilayah ini. Namun keberadaan meriam kuno berhubungan dengan soal ekspansi ekonomi, mengingat daerah Ambalau adalah salah satu penghasil komoditi cengkeh.

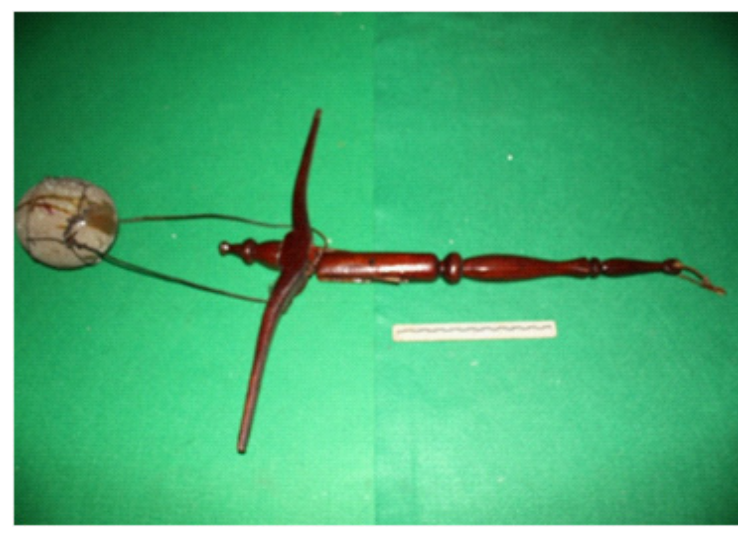

Foto 4. Timbangan Zakat atau Batu Zakat yang ersimpan di Masjid Kuno Ulima arsitekturalnya (Sumber: Dok. Balai Arkeologi Ambon, 2011).

Timbangan zakat fitrah terbuat dari bahan kayu yang berkualitas baik dan tahan lama. Ukuran panjang kayu timbangan panjang $45 \mathrm{~cm}$, dengan pemberat berupa batu panjang $45 \mathrm{~cm}$, dengan pemberat berupa batu
karang laut seberat $2,5 \mathrm{Kg}$. Alat pembakaran kemenyan juga tersimpan di dalam majid sebagai salah satu alat kelengkapan masjid. Alat pembakaran kemenyan ini terdiri dari dua komponen, pertama berupa batu yang ditengahnya berlobang atau cekung yang mungkin digunakan untuk menunmbuk kemenyan sebelum dibakar. Alat kedua berupa alat pembekaran sederhana.

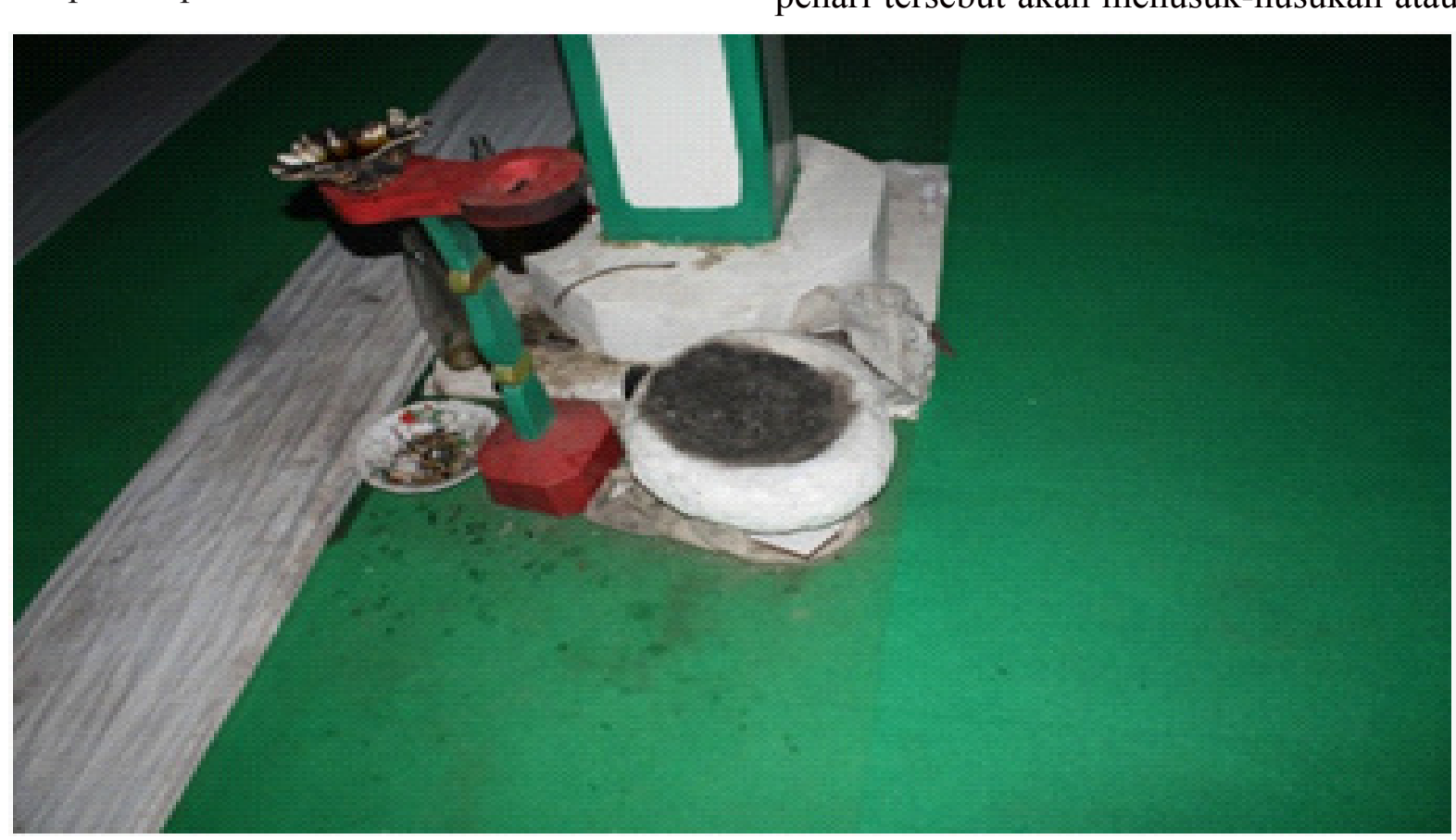

Foto 5. Alat pembakaran kemenyan yang tersimpan di dalam majid kuno Ulima (Sumber: Dok. Balai Arkeologi Ambon, 2011).
Hasil survey di pesisir pantai desa Ulima juga ditemukan adanya konsentrasi keramik asing dan gerabah dalam kuantitas yang cukup banyak. Konsentrasi gerabah dan keramik, berada pada lokasi yang dekat dengan pesisir pantai yang terletak memanjang epanjang areal pinggir desa di sepanjang pesisir pantai. Lokasi ini tidak jauh dari lokasi pelabuhan desa Ulima sekarang.

Sebelumnya, Sudarmika (1997) melaporkan bahwa terdapat data arkeologi berupa alat Debus di Dusun Kampung yang terbuat dari kayu dan besi. Unsur kayu terdapat pada bgain pangkal atau tempat pemegangan dengan diameter 10 $\mathrm{cm}$ sedangkan tebalnya/tingginya $15 \mathrm{~cm}$ Adapun unsur dari besi terdapat pada bagian tengah dari kayu yang dilekatkan atau dipasangkan dengan dengan sangat kuat, panjang besi $26 \mathrm{~cm}$ dan diameternya $10 \mathrm{~mm}$. pada bagian ujungnya dibuat lancipan yang sangat runcing. Alat ini digunakan oleh orang yang khusus artinya penggunaannya tidak boleh dilakukan oleh orang sembarangan, karena pada saat tarian Debus ditarikan penari tersebut akan menusuk-nusukan atau Baru yang masih wilayah administrative desa Ulima.. Alat ini terdiri dari dua buah 
menikamkan dengan kerasnya bagian yang runcing dari alat tersebut ke beberapa bagian tubuh (terutama dada) si penari, tapi karena si penari sudah dilengkapi dengan ilmu kebal sehingga tubuhnya tidak sampai luka hanya bajunya saja robek-robek.

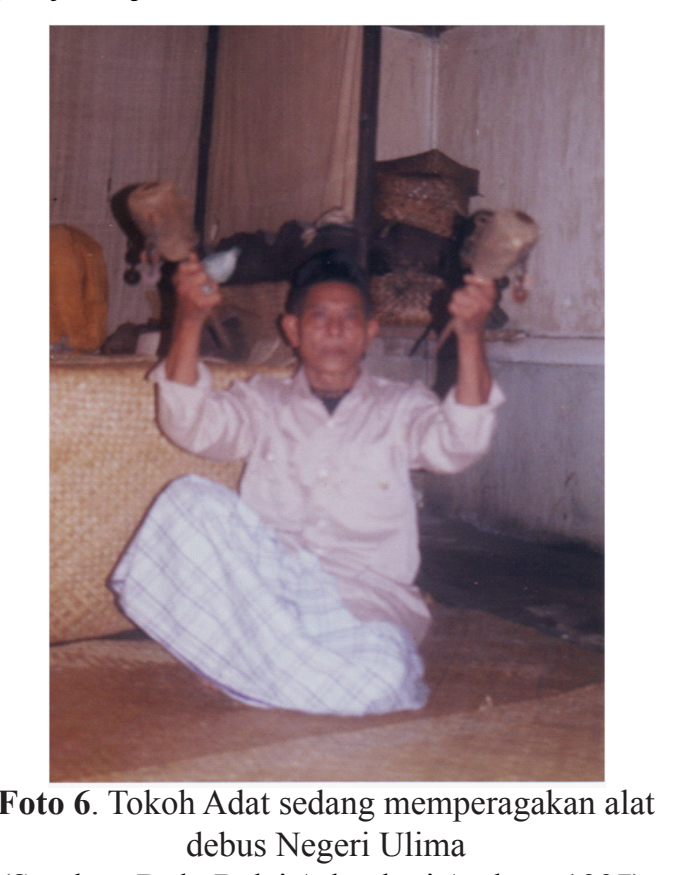

(Sumber: Dok. Balai Arkeologi Ambon, 1997).

Berdasarkan temuan arkeolog tersebut, tampaknya dapat memberikan gambaran tentang perkembangan religi masyarakat Pulau Ambalau. Temuan data arkeologi praejarah berupa batu lobang, memberikan petunjuk bahwa mayarakat sejak masa pra Islam udah mengenal bentuk religi dan kepercayaan lokal yang berhubungan dengan roh leluhur. Oleh karena itu munculnya Islam, tidak menghilangkan kepercayaan lokal yang udah tumbuh dan tertanam kuat Sebaliknya kepercayaan lokal terintegrasi dengan agama Islam.

Tradisi Makam Berundak dan

\section{Perkembangan Islam Lokal}

Hasil penelitian arkeologi di wilayah Ambalau, sesungguhnya belum dapat dijadikan bahan untuk perluasan interpretasi. Namun dalam konteks tradisi makam kuno Islam menunjukkan adanya karakteristik Islam yang tidak bisa dilepaskan dari kepercayaan lokal. Di wilayah Pulau
Ambalau, berdasarkan bukti-bukti arkeologis, sebelum Islam, masyarakat sudah mengenal tradisi religi yang jejak-jejak materialnya dapat kita lihat sampai sekarang. Temuan batu dapat kita lihat sampai sekarang. Temuan batu
lubang, memberikan keyakinan bahwa pada masa pra Islam, kehidupan sudah berkembang, termasuk dalam kehidupan religi. Dalam teor konstruksi sosial Peter Berger dan Thomas Luckman dijelaskan mengenai bagaimana eksternalisai nilai yang masih dianggap sebagai faktor luar bagi dirinya diterima dan diadaptasikan dalam lingkungannya Proses ini kemudian terobjektivasi menjadi keasadaran bersama sebagai pemiliki ajaran agama tersebut (Berger dan Luckman, 1990). Dalam konteks perkembangan Islam, tampaknya bentuk lokalitas atau varian Islam tampaknya bentuk lokalitas atau varian Islam
lokal, dalam wujud material berupa tradisi makam berundak, yang dapat dijumpai hingga sekarang, menujukkan bahwa nilai-nilai Islam dipahami pula sebagai bentuk sinergitas antara Islam sebagai teks ajaran dalam konstruksi nilai-nilai budaya lokal. Oleh karena itu bentuk integrasi nilai-nilai ajaran Islam dan budaya lokal atau tradisi setempat, merupakan konsensus atau keepakatan bersama oleh komunita muslim lokal. Konsensus terhadap hal itu menjadi pola perilaku terus menerus yang menggambarkan identitas Islam lokal, pada masa awal perkembangan Islam dan terus berlanjut dalam proses perubahan sosial budaya hingga sekarang. Tampaknya kita dapat berinterpretasi berdasarkan data arkeologi yang ditemukan di Pulau Ambalau, yakni adanya keberlanjutan atau bertahannya sistem religi masyarakat pada masa megalitik yang terus betahan hingga memasuki zaman ketika masyarakat mengkonversi agama Islam. Tampak bahwa komunitas masyarakat, yang saat ini adalah keberlanjutan budaya dari masyarakat sebelumnya.

Salah satu penyebab munculnya nisan tipe berundak, jika mengacu pendapat Ambary (1986, 1991) muncul karena latar belakang sejarah budaya nusantara yang permisive terhadap anasir apapun yang datang dari luar. Masyarakat nusantara tidak pernah menolak anasir asing, tetapi harus melewati pengolahan, pengimbuhan, penggubahan dan sebagainya. Kreativitas mengubah dan mengubah anasir asing menjadi anasir dan mengubah anasir asing menjadi anasir nusantara merupakan strategi adaptasi, karena
proses seleksi sampai disosialisasikan sebagai pranata perilaku (Ambary, 1986; Ambary 1991: 21). Tumbuh dan berkembangnya budaya Islam di Nusantara, menghasilkan dan meninggalkan peradaban yang secara ideologis bersumber pada Alqur'an dan Al-hadist. Sementara itu secara fisik memperlihatkan anasir kesinambungan dengan anasir budaya pra-Islam (Ambary, 1991:1). Kehadiran unsur Pra Islam dalam kriya masyarakat Nusantara menggambarkan bahwa unsur-unsur lokal masih merupakan afirmasi paling kuat dan paling energetik dalam menciptakan bentukbentuk budaya (Mahmud, 2001:74). Buktibukti arkeologis dalam bentuk material makam Islam kuno dapat memberi petunjuk, bahwa masyarakat di satu pihak telah mendapat pengaruh budaya Islam, namun secara fisikal masih memperlihatkan dominasi unsur budaya lokal, yakni memperlihatkan kesinambungan dengan anasir budaya Pra Islam, yang oleh Ambary $(1986 ; 1991)$ disebut sebagai permanensi etnologis. Dalam konstruksi masyarakat lokal, Islam dipahami sebagai bentuk pewarisan, sehingga kultur Islam merupakan bagian dari proses tradisi. Hal ini semakin menemukan identitasnya, ketika dipertemukan dengan tradisi lokal, oleh karena itu bentuk makam yang ada, menujukkan identitas kelokalan Islam.

Meski demikian, karakteristik Islam yang tekstual sebagaimana Islam dalam konsep agama wahyu yang transedental, tetap memiliki ruang untuk tetap bertahan. Hukum syariat tentang zakat misalnya tetap bertahan dengan bukti adanya temuan timbangan zakat atau masyarakat menyebutnya batu zakat yang tersimpan di Masjid Ulima. Namun di sisi lain, adanya data artefaktual berupa tempat pembakaran kemenyan, yang kuat karakter pra Islamnya, sebagai perangkat ritus penghormatan terhadap leluhur menunjukkan bahwa budaya lokal maih sangat kuat menjadi bagian dari kontruksi ke Islaman masyarakat setempat. Dengan demikian, Islam yang berkembang menunjukkan karakter Islam yang integratif dan akomodatif terhadap paham kepercayaan lokal masyarakat setempat.

\section{PENUTUP}

Dari penelitian arkeologi ini, dapat disimpulkan bagaimana dinamika budaya masyaraat sejak awal konversi Islam hingga perkembangannya, ketika Islam telah menjadi agama yang dianut oleh sebagian besa masyarakat Pulau Ambalau. Karakteristik Islam lokal, sangat akomodatif terhadap unsur-unsur lokal. Keberadaan makammakam kuno berundak, menunjukkan bentukbentuk penghormatan terhadap leluhur yang merupakan basis kepercayaan yang berkembang pada masa prasejarah.

Oleh karena itu bentuk makam berundak, juga sebagai bentuk tradisi makam yang berlanjut, merupakan keberlanjutan tradisi megalitik, hal ini menunjukkan bahwa Islam sangat adaptif terhadap unur-unsur lokal. Upaya integrasi Islam dengan buday leluhur yakni pemujaan terhadap leluhur, tampaknya merupakan kepercayaan yang sangat kuat pada masyarakat lokal Ambalau. Oleh karenanya, penerimaan Islam, tanpa menegasikan tradisi-tradisi dan kepercayaan terhadap religi lama, yakni kepercayaan terhadap arwah leluhur, yang hidup jauh sebelum Islam hadir di Pulau Ambalau. 


\section{DAFTAR PUSTAKA}

Ambary, Hasan Muarif, 1986 Unsur Tradisi Pra Islam Pada Sistem Pemakaman Islam di Indonesia. Pertemuan Ilmiah Arkeologi IV. Jakarta: Depdikbud. , 1991 Makam-Makam Kesultanan dan Para Wali Penyebar Islam di Pulau Jawa.Aspek-Aspek Arkeologi Indonesia. Jakarta: Pusat Penelitian Artkeologi Nasional.

, 1998. Menemukan Peradaban Arkeologi dan Islam di Indonesia. Jakarta: Pusat Penelitian Arkeologi Nasional. Logos. Wacana Ilmu.Jakarta.

Berger, Peter L dan Luckman Thomas, 1990, Tafsir Sosial atas Kenyataan. Risalah tentang Sosiologi Pengetahuan. Jakarta: Penerbit LP3ES

Mahmud, Irfan 2001 Determinasi Budaya Islami di Wilayah Pinggiran Kekuasaan Bugis. WalannaE. Jurnal Arkeologi Sulawesi Selatan dan Tenggara. Vol IV No 6 Juni. Makassar: Balai Arkeologi Makassar.

, 2003 Kota Kuno Palopo: Dimensi Fisik, Sosial dan Kosmologi. Makassar: Masagena Press.

Sudarmika, GM 1997, Penelitian Arkeologi di wilayah Pulau Ambalau. Laporan Penelitian. Ambon: Balai Arkeologi Ambon. Tidak terbit

Tim Penelitian, 2011 Penelitian Arkeologi Pengaruh dan Perkembangan Islam di Wilayah Pulau Ambalau. Laporan Penelitian. Ambon: Balai Arkeologi Ambon. Tidak terbit 